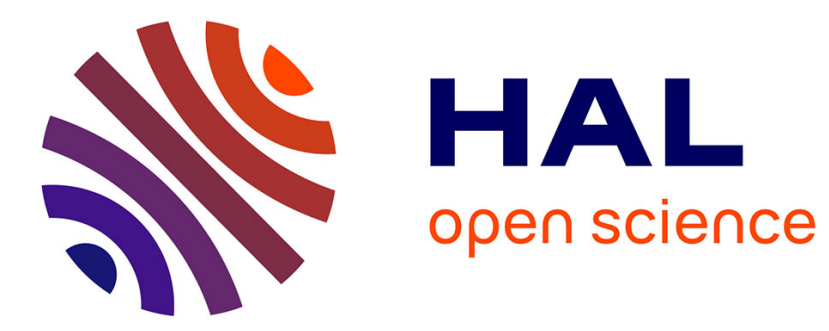

\title{
Laser surface alloying of 316L stainless steel: different hardening routes and related microstructures
}

\author{
F. Laroudie, C. Tassin, M. Pons
}

\section{To cite this version:}

F. Laroudie, C. Tassin, M. Pons. Laser surface alloying of 316L stainless steel: different hardening routes and related microstructures. Journal de Physique IV Proceedings, 1994, 04 (C4), pp.C4-77C4-80. 10.1051/jp4:1994415 . jpa-00252605

\section{HAL Id: jpa-00252605 https://hal.science/jpa-00252605}

Submitted on 1 Jan 1994

HAL is a multi-disciplinary open access archive for the deposit and dissemination of scientific research documents, whether they are published or not. The documents may come from teaching and research institutions in France or abroad, or from public or private research centers.
L'archive ouverte pluridisciplinaire HAL, est destinée au dépôt et à la diffusion de documents scientifiques de niveau recherche, publiés ou non, émanant des établissements d'enseignement et de recherche français ou étrangers, des laboratoires publics ou privés. 


\title{
Laser surface alloying of 316L stainless steel: different hardening routes and related microstructures
}

\author{
F. LAROUDIE, C. TASSIN and M. PONS
}

Laboratoire Science des Surfaces et Matériaux Carbonés, URA 413 du CNRS, ENS d'Electrochimie et d'Electrométallurgie de Grenoble, Institut National Polytechnique de Grenoble, Domaine Universitaire, BP. 75, 38402 Saint-Martin-d'Hères, France

\begin{abstract}
The goal of this study is to investigate different hardening routes for $316 \mathrm{~L}$ stainless steel by laser surface alloying. We have investigated the incorporation of hard submicronic particles of $\mathrm{TiC}$, the precipitation of titanium carbide from mixtures of $\mathrm{Ti}$ and $\mathrm{SiC}$ and the formation of iron-chromium carbides by carbon incorporation. For each hardening route we present the microstructure and the hardness of the processed surface alloys and the conditions leading to the best compromise between highest hardness, best homogeneity and lowest occurence of cracks. From these results it can be reasoned that hardening by iron-chromium carbides is the best route and that this surface alloy is a good candidate for some tribological applications.
\end{abstract}

\section{INTRODUCTION}

The more traditional way for improving or altering the surface properties of solids involves the deposition of films and coatings from solid, liquid and vapor sources. A more recent approach is based on the modification of existing surfaces using directed energy sources such as lasers [1-2]. We focus this study on laser-surface alloying of $316 \mathrm{~L}$ stainless steel. This process consists of melting the surface of the base alloy with known amounts of predeposited materials. The $316 \mathrm{~L}$ austenitic stainless steel is widely used owing to its high corrosion resistance, but, due to its low hardness $(200 \mathrm{HV})$, its tribological properties are very poor. Moreover, because of its austenitic structure, it cannot be hardened by heat treatment and therefore there is no easy means for improving its wear resistance. Different hardening routes for the $316 \mathrm{~L}$ austenitic stainless steel using laser alloying were investigated, (i) formation of iron-chromium carbides by carbon and $\mathrm{SiC}$ incorporation, (ii) incorporation of submicronic particles of TiC, (iii) precipitation of titanium carbides.

\section{RESULTS}

The substrate material used for the experiments was the austenitic stainless steel $316 \mathrm{~L}$. The samples, about $5 \mathrm{~mm}$ thick were mechanically polished before laser irradiation. The different powders, $\mathrm{TiC}, \mathrm{SiC}, \mathrm{Ti}+\mathrm{SiC}$ and $\mathrm{C}$ were deposited onto the surface. Surface alloying was carried out using a $300 \mathrm{~W}$ continuous wave Nd-YAG laser with argon as a shielding gas to prevent oxidation. The beam was guided by an optical fiber to give a circular spot of 950 $\mu \mathrm{m}$ in diameter leading to a maximum power density of $4.10^{8} \mathrm{~W} / \mathrm{m}^{2}$. The criteria for determining the quality of the coatings were a compromise between highest hardness, best homogeneity and lowest occurence of cracks.

SiC alloying

$\mathrm{X}$-ray diffraction analysis showed that the surface alloy is composed of austenite $(\gamma)$ and $\mathrm{M}_{7} \mathrm{C}_{3}$ carbides $(\mathrm{M}=\mathrm{Fe}, \mathrm{Cr})$. It is thought that the high temperatures (superior to $3000^{\circ} \mathrm{C}$ ) 
reached during the treatment lead to the decomposition of $\mathrm{SiC}$ in silicon and carbon. During the solidification, silicon, and maybe some amounts of carbon dissolve in austenite, the remaining carbon leading to carbide precipitation. A micrograph of the laser alloyed region (about $150 \mu \mathrm{m}$ thick) is illustrated in fig. 1. The structure consists of primary austenite cells or dendrites surrounded by a fine eutectic containing $\mathrm{M}_{7} \mathrm{C}_{3}$ carbides. Microhardness measurements revealed a mean value of $500-600 \mathrm{HV}$ in the melted area. With the process parameters used, the surface alloy is crack-free. For higher surface coverages cracks are frequently observed due to the formation of a much harder $(1000 \mathrm{HV})$ but brittle phase.

\section{Carbon alloying}

In order to complete our understanding on the role of the carbon in the hardening of $316 \mathrm{~L}$ stainless steel, we have focussed our attention on the incorporation of carbon alone. Xray diffraction analysis revealed the presence of austenite $(\gamma)$ and carbides $M_{7} C_{3}(M=C r$, Fe). Figure 2 shows the microstructure of the alloyed layer. The periphery of the tracks exhibits a dendritic $(\gamma)$ microstructure leading to an averaged microhardness of $400 \mathrm{HV}$, whereas the top center of the tracks displays a higher microhardness $(650 \mathrm{HV})$ : the related structure still couldn't be observed by SEM, but it was interpreted as an eutectic austenitecarbides. The concentration of carbon in the supposed eutectic area, measured by EPMA is about $3.0 \mathrm{wt} \%$.

\section{TiC submicronic particles alloying}

$\mathrm{X}$-ray diffraction analysis showed the presence of $\mathrm{TiC}$ and austenite $(\gamma)$ within the alloyed layer. The alloyed layer appears to be crack-free, but heterogeneous. Some large clusters of TiC, from 10 to $50 \mu \mathrm{m}$ in size are distributed within the alloy. Outside these areas, the alloyed layer exhibits a regular microstructure (fig 3) composed of austenite grains (dendrites) with $\mathrm{TiC}$ located in the interdendritic spacings. Some faceted crystals of $\mathrm{TiC}$, about $1 \mu \mathrm{m}$ in size, are also present, regularly distributed within the alloyed layer. This microstructure exhibits only a slight increase in microhardness (about $280 \mathrm{HV}$ ).

\section{$\mathbf{T i}+\mathrm{SiC}$ alloying}

Laser alloying of $316 \mathrm{~L}$ stainless steel with a mixture of titanium and $\mathrm{SiC}$ was planned because, in one hand, laser alloying with submicronic TiC particles had lead to the formation of TiC agregates irregularly dispersed in the resulting surface alloy; on the other hand, when using $\mathrm{SiC}$, our observations have shown that $\mathrm{SiC}$ was totally dissociated into $\mathrm{Si}$ and $\mathrm{C}$ during laser melting. Therefore, laser melting of $\mathrm{a} \mathrm{Ti}+\mathrm{SiC}$ coating appeared as an interesting route to obtain a surface alloy enriched in silicon for corrosion applications [2], and strengthened by hard TiC precipitates resulting from the carburization of $\mathrm{Ti}$. The different phases detected by X-ray diffraction are austenite $(\gamma)$, TiC and ferrite $(\alpha)$. The formation of ferrite is the result of the presence of silicon which is ferrite former. A regular dispersion of fine $\mathrm{TiC}$ precipitates, about 0.5 to $1 \mu \mathrm{m}$ in diameter was evidenced by SEM (fig. 4). The average microhardness of the surface alloy fluctuates between $350 \mathrm{HV}$ and $700 \mathrm{HV}$.

\section{CONCLUSION}

We have shown that $316 \mathrm{~L}$ austenitic stainless steel can be hardened by laser surface alloying. The tribological and hot corrosion properties of these coatings will be characterized.

\section{REFERENCES}

1. F. FOUQUET, J.M. PELLETIER, M. PILLOZ and A.B. VANNES, in "Laser de puissance et traitements des matériaux", edited by A.B. VANNES (Presses Polytechniques et Universitaires, Lausanne, Suisse, 1991) p. 217.

2. A.Y. FASASI, S.K. ROY, M. PONS, A. GALERIE, D. SIBUET and M. CAILLET, in MAT-TEC 92, edited by A. NIKU-LARI, (IITT International, Gournay/Marne, France, 1992) p. 211. 


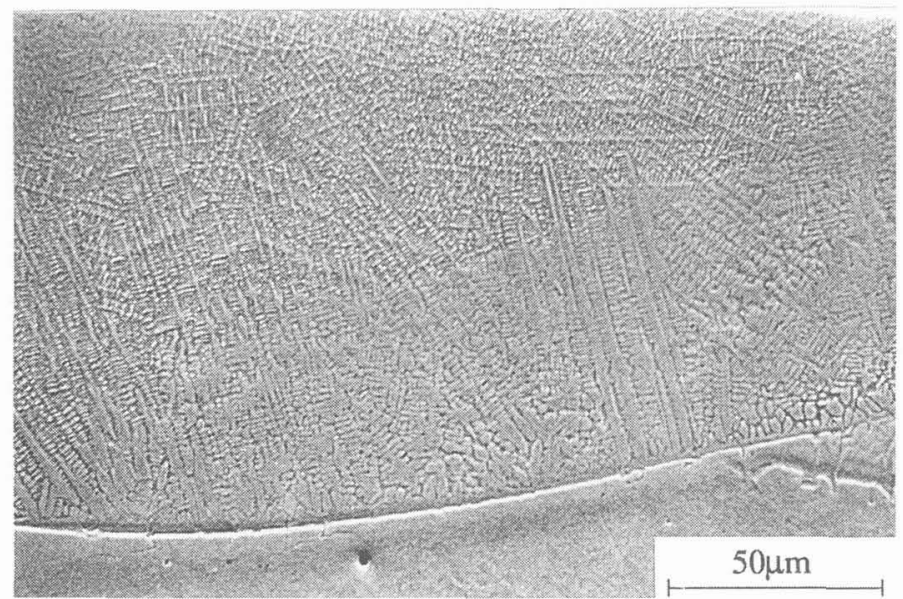

Fig. 1 : SEM photomicrograph of a $316 \mathrm{~L}$ - SiC sample showing the dendritic microstructure (surface coverage $=5.5 \mathrm{mg} / \mathrm{cm}^{2}, \mathrm{P}=200$ $\mathrm{W}, \mathrm{v}=10 \mathrm{~mm} / \mathrm{s}$ )

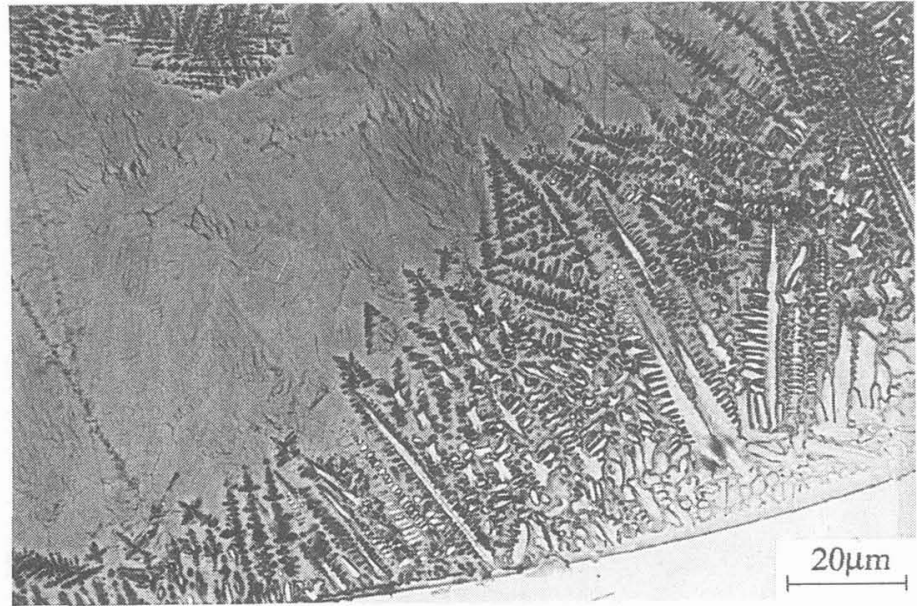

Fig. 2: SEM photomicrograph of a 316L - C sample showing the dendritic and eutectic microstructures (surface coverage $=5$ $\left.\mathrm{mg} / \mathrm{cm}^{2}, \mathrm{P}=200 \mathrm{~W}, \mathrm{v}=5 \mathrm{~mm} / \mathrm{s}\right) ;$ concentration of $\mathrm{C}$ in the eutectic region (measured by EPMA) : about $3 \mathrm{wt} \%$. 


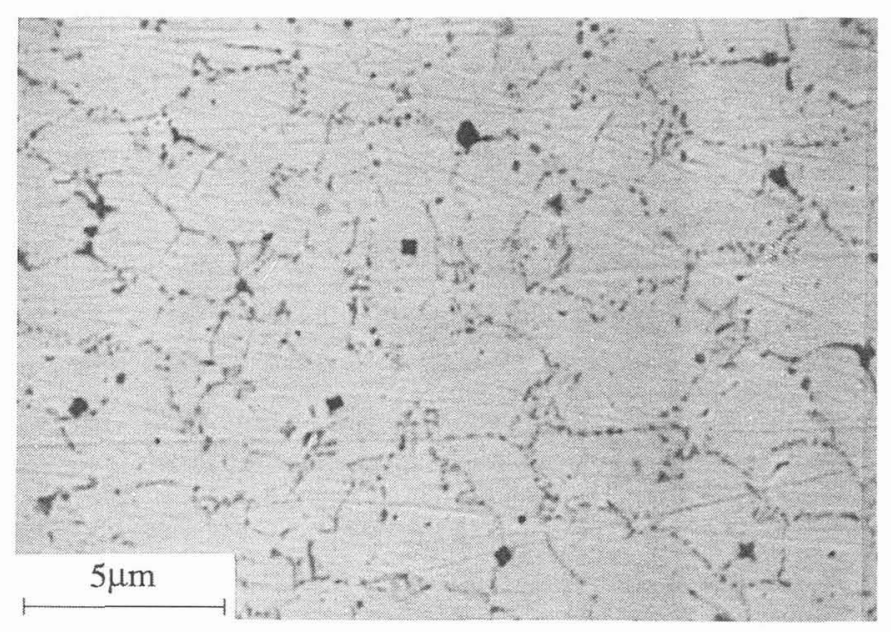

Fig. 3 : Backscattered electron image of a 316L - TiC sample showing the microstructure outside the agregates (surface coverage $=15 \mathrm{mg} / \mathrm{cm}^{2}$ in 5 times, $\left.\mathrm{P}=200 \mathrm{~W}, \mathrm{v}=10 \mathrm{~mm} / \mathrm{s}\right)$; concentration of TiC (measured by EPMA) : 3.5 wt $\%$.

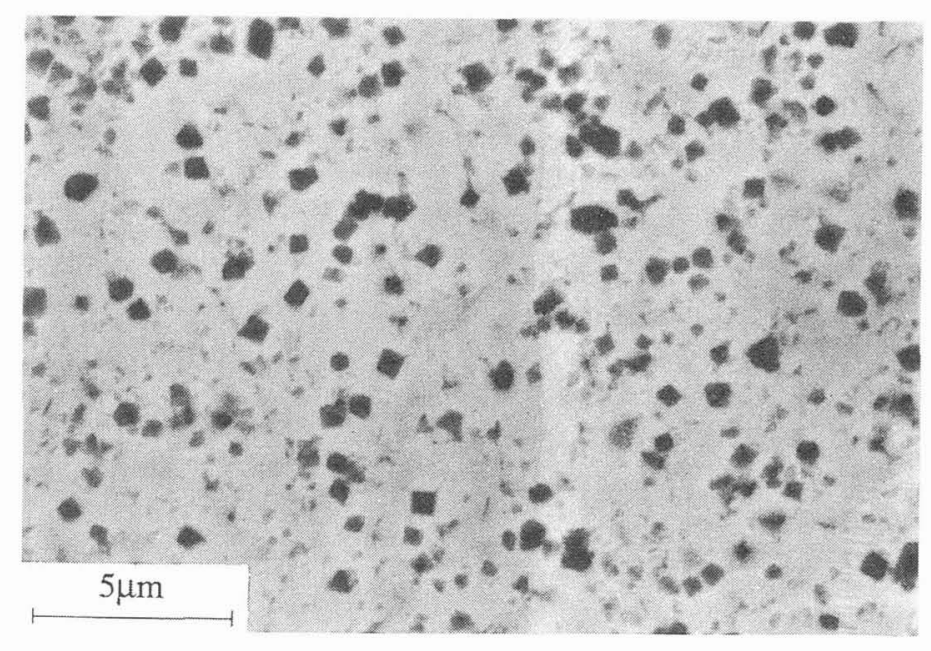

Fig. 4 : Backscattered electron image of a $316 \mathrm{~L}-\mathrm{Ti}+\mathrm{SiC}$ sample ( surface coverage $=7.5 \mathrm{mg} / \mathrm{cm}^{2} \mathrm{P}=200 \mathrm{~W}, \mathrm{v}=5 \mathrm{~mm} / \mathrm{s}$ ); concentration of TiC (measured by EPMA) : about $8 \mathrm{wt} \%$. 